\title{
Probiotic Properties of Bacillus Strains Isolated from Stingless Bee (Heterotrigona itama) Honey Collected across Malaysia
}

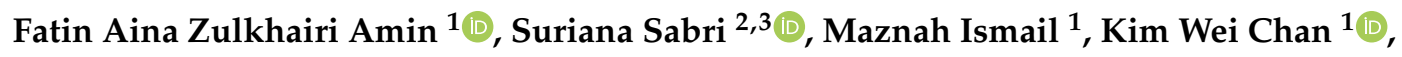 \\ Norsharina Ismail ${ }^{1}$, Norhaizan Mohd Esa ${ }^{1,4}{ }^{\mathbb{D}}$, Mohd Azmi Mohd Lila ${ }^{5}$ and \\ Norhasnida Zawawi ${ }^{1,6}$, (D) \\ 1 Laboratory of Molecular Biomedicine, Institute of Bioscience, Universiti Putra Malaysia, Serdang 43400, \\ Selangor, Malaysia; GS50839@student.upm.edu.my (F.A.Z.A.); maznahis@upm.edu.my (M.I.); \\ chankim@upm.edu.my (K.W.C.); norsharina@upm.edu.my (N.I.); nhaizan@upm.edu.my (N.M.E.) \\ 2 Enzyme and Microbial Technology Research Center, Faculty of Biotechnology and Biomolecular Sciences, \\ Universiti Putra Malaysia, Serdang 43400, Selangor, Malaysia; suriana@upm.edu.my \\ 3 Department of Microbiology, Faculty of Biotechnology and Biomolecular Sciences, Universiti Putra Malaysia, \\ Serdang 43400, Selangor, Malaysia \\ 4 Department of Nutrition and Dietetics, Faculty of Medicine and Health Sciences, Universiti Putra Malaysia, \\ Serdang 43400, Selangor, Malaysia \\ 5 Department of Veterinary Pathology and Microbiology, Faculty of Veterinary Medicine, Universiti Putra \\ Malaysia, Serdang 43400 UPM, Selangor, Malaysia; azmi@upm.edu.my \\ 6 Department of Food Science, Faculty of Food Science and Technology, Universiti Putra Malaysia, \\ Serdang 43400, Selangor, Malaysia \\ * Correspondence: norhasnida@upm.edu.my
}

Received: 7 October 2019; Accepted: 1 November 2019; Published: 31 December 2019

\begin{abstract}
This study aimed to isolate, identify, and evaluate the probiotic properties of Bacillus species from honey of the stingless bee Heterotrigona itama. Bacillus spp. were isolated from five different $H$. itama meliponicultures, and the isolates were characterized through Gram-staining and a catalase test. Tolerance to acidic conditions and bile salt $(0.3 \%)$, hydrophobicity, and autoaggregation tests were performed to assess the probiotic properties of the selected isolates, B. amyloliquefaciens HTI-19 and B. subtilis HTI-23. Both Bacillus isolates exhibited excellent antimicrobial activity against both Gram-positive and Gram-negative bacteria and possessed significantly high survival rates in $0.3 \%$ bile solution for $3 \mathrm{~h}$. Their survival rates in acidic conditions were also comparable to a commercial probiotic strain, Lactobacillus rhamnosus GG. Interestingly, the hydrophobicity and autoaggregation percentage showed no significant difference from L. rhamnosus GG, a commercial probiotic strain. The results from this study suggest that B. amyloliquefaciens HTI-19 and B. subtilis HTI-23 isolated from stingless bee honey have considerably good probiotic properties. Therefore, more studies should be done to investigate the effects of these bacteria cultures on gastrointestinal health.
\end{abstract}

Keywords: stingless bee honey; probiotic Bacillus strains; molecular identification; antimicrobial activity; pathogenic bacteria

\section{Introduction}

Stingless bee species are native to the tropics and subtropics of the world, including Australia, Africa, Southeast Asia, and parts of Mexico and Brazil. They are known for their role as important pollinators of both wild and cultivated flowering plants in different crops and orchards [1]. They produce honey, a natural sweet substance originating from nectar or blossoms that the bees collect, transform, and combine 
with specific substances of their own to ripen and mature [2]. Stingless bee honey is considered to be natural and organic food with high nutritional and therapeutic value [3]. It has significantly higher moisture content, water activity, ash content, and free acidity than does honeybee honey, while the $\mathrm{pH}$ and total soluble solid content are slightly lower [4]. Other than those components, proteins, amino acids, enzymes, organic acids, mineral elements, and vitamins are also present in honey, but only in small amounts $[5,6]$. These characteristics, especially lower reducing sugars and higher moisture content compared to the honey of honeybees, will eventually lead to the fermentation of stingless bee honey [7].

The fermentation of honey involves the presence of fungi (filamentous and yeast) and lactic acid bacteria, making stingless bee honey a plentiful source of microorganisms, with some of them exhibiting probiotic characteristics [8-10]. In addition, the humid and warm environment in a beehive provides optimum conditions for the growth of certain microbes. Bacillus spp. are Gram-positive and spore-former bacteria that can be widely found in soil and plants. However, due to their spore-forming characteristics, which are highly stable in acidic $\mathrm{pH}$, they can also colonize different environments, such as honey and various food matrices [11]. For example, Bacillus species such as B. subtilis, B. licheniformis, B. pumilus, and B. amyloliquefaciens have been detected in the fermentation of both stingless bee honey and Apis mellifera honey [12,13]. These bacteria have advantages over non-spore formers such as lactic acid bacteria (LAB) due to their heat-resistant spores [14].

The identification of Bacillus species with antimicrobial properties might provide additional commercial value to stingless bee honey. The presence of Bacillus spp. in honey could originate from the bee itself or other environmental factors such as pollen, dust, and air [15]. Bacillus and many other genera, such as Lactobacillus, Lactococcus, Bifidobacterium, Leuconostoc, and Pediococcus are regarded as probiotics [16]. Probiotics are defined as "live microorganisms in which, when administered in adequate amounts, will confer a health benefit to the host" [17]. B. subtilis of different strains has been included as a dietary supplement in both human and animal diets through selected fermented foods such as natto, soybean, or any other probiotic supplement [18-20].

Most of the bacteria in the genus Bacillus are not harmful to mammalians, with the exception of B. cereus and B. anthracis. Bacillus spp. produce a vast variety of functional secondary metabolite-like antibiotics, bioinsecticides, enzymes, and lipopeptides, such as iturin, surfactin, fengycins, bacteriocins, and bacteriocin-like inhibitory substances (BLISes), which are also known as antimicrobial compounds. These biologically and commercially important characteristics make them a suitable candidate for uses as probiotic bacteria $[11,21,22]$. The significant role of probiotics is based on their antagonistic or antimicrobial activities against enteropathogenic bacteria. This is generally a result of bacteriocin secretion by the probiotic cultures or competitive metabolic interactions between probiotics and pathogens $[23,24]$.

Most studies of the microorganisms associated with stingless bees have been carried out with the objective of describing the bacterial and fungal communities associated with these bees. While there have been extensive studies on LAB isolated from honeybees and stingless bee honey, little is known about the antimicrobial potential of Bacillus strains from the honey of Heterotrigona itama against some pathogenic bacteria. Herein, the study aimed to isolate, identify, and assess the probiotic properties of Bacillus species from the raw honey of H. itama from different meliponiculture places in Malaysia. To our knowledge, data on the strains and bioactivity of Bacillus species in raw stingless bee honey in Malaysia are still scarce, and therefore this study might provide some information on the probiotic properties of the nonpathogenic Bacillus strains isolated from the honey of $H$. itama.

\section{Materials and Methods}

\subsection{Honey Samples}

Fifty milliliters of five raw honey samples were directly collected from the stingless beehives $(H$. itama) of different local apiarists located in Seri Kembangan (Selangor), Serdang (Selangor), Batang Benar (Negeri Sembilan), Segamat (Johor), and Sematan (Sarawak). Collected samples were stored in a sterile bottle at $4{ }^{\circ} \mathrm{C}$ before further analysis. 


\subsection{Isolation of Bacterial Strains from Stingless Bee Honey}

Five-milliliter aliquots of stingless bee honey were added to $5 \mathrm{~mL}$ of nutrient broth (Oxoid, Basingstoke, $\mathrm{UK}$ ) and incubated at $37^{\circ} \mathrm{C}$ for $24 \mathrm{~h}$. The culture was transferred to a 50-mL centrifuge tube and spun at $1500 \times g$ for $15 \mathrm{~min}$, and then the supernatant was discarded. A total of $100 \mu \mathrm{L}$ of $0.85 \%$ saline was added into the pellet and homogenized by vortexing for $10 \mathrm{~s}$. The mixture was then spread onto nutrient agar (Oxoid, Basingstoke, UK) through the spread-plate method. All experiments were done in triplicate. After being dried, the plates were incubated at $37^{\circ} \mathrm{C}$ for $16-24 \mathrm{~h}$. The bacterial isolates were streaked onto new plates to obtain a single colony. The colonies and microscopic morphologies were observed. A catalase test and Gram staining were performed according to Patel et al. [25].

\subsection{Bacterial Strains and Growth Conditions}

A total of 23 Bacillus strains isolated from stingless bee honey were included in this study. Pathogenic strains (Escherichia coli, Salmonella thyphimurium, Klebsiella pneumonia, Pseudomonas aeruginosa, and Staphylococcus aureus) were kindly supplied by the Enzyme and Microbial Technology Research Center, Faculty of Biotechnology and Biomolecular Sciences, Universiti Putra Malaysia, Malaysia. The strains were maintained at $-80^{\circ} \mathrm{C}$ in nutrient broth (Oxoid, Basingstoke, UK) with $20 \%$ (v/v) glycerol and were propagated three times in nutrient broth for activation prior to experimental use.

\subsection{Identification of Bacteria Using Molecular Technique}

Genomic DNA Extraction, 16S rRNA Amplification, and Gene Analysis

Genomic DNA from pure cultures was extracted using a GF-1 Bacterial DNA Extraction Kit (Vivantis Technologies Sdn Bhd, Malaysia) according to the manufacturer's instructions: 16S rRNA genes were amplified using a set of universal primers, 27F (5'-AGAGTTTGATCCTGGCTCAG-3') and 1429R (5'-CGTTACCTTGTTACGACTT-3') [26]. All PCR reactions were performed in 2X Taq Master Mix (Vivantis Technologies Sdn. Bhd., Malaysia) and amplified using a Thermal XP Cycler (BIOER Technology). PCR amplicons were sent for sequencing to MyTACG Bioscience Enterprise, Malaysia. The sequences obtained were analyzed using National Center of Biotechnology Information (NCBI) BLAST, and phylogenetic trees were constructed using MEGA7 software [27]. The following strains were used as a reference sequence for the phylogenetic analysis: B. altitudinis strain bacteria VII (KT427442), B. pumilus strain ML568 (KC692176), B. pumilus strain HB29 (KM659230), B. subtilis strain BSFLG01 (MF196314), B. amyloliquefaciens strain BA17 (MH891764), B. amyloliquefaciens strain 13 (HM107806), B. megaterium strain SX1 (MF431747), B. aryabhattai SX3 (MF431749), and Salmonella enterica spp. enterica strain LT2 as the outgroup.

\subsection{Antimicrobial Activity Assessment}

Antimicrobial activity was assessed using an agar well-diffusion method with slight modifications [28]. The turbidity of bacterial suspensions, adjusted to match the standard McFarland 0.5 (approximately $10^{8}$ colony forming unit, $\mathrm{CFU} / \mathrm{mL}$ ), was spread onto the plate. A 7-mm diameter well was punched aseptically onto the Mueller-Hinton agar (Oxoid, Basingstoke, UK) using the reverse end of a sterile 1-mL pipette tip. Tetracycline $(20 \mu \mathrm{g} / \mathrm{mL})$ was used as a positive control. A total of $100 \mu \mathrm{L}$ of test agent was seeded into each well. A probiotic strain, Lactobacillus rhamnosus strain GG, was used as the reference strain. After incubation at $37^{\circ} \mathrm{C}$ for $16-24 \mathrm{~h}$, the diameter of the clear zone was measured.

\subsection{Screening for Probiotic Properties}

\subsubsection{Acid and Bile Tolerance}

Acid and bile tolerance were performed according to the method described by Klingberg et al. [29], with slight modifications. Bile tolerance was examined in nutrient broth (Oxoid, Basingstoke, UK) containing $0.3 \%(\mathrm{w} / \mathrm{v})$ oxgall bile (Sigma-Aldrich, St. Louis, MO, USA). A volume of $100 \mu \mathrm{L}$ of cell 
suspensions of Bacillus strains cultured for $18 \mathrm{~h}$ (approximately $10^{7} \mathrm{CFU} / \mathrm{mL}$ ) were inoculated into nutrient broth (Oxoid, Basingstoke, UK) without bile and into nutrient broth (Oxoid, Basingstoke, UK) containing $0.3 \%\left(\mathrm{w} / \mathrm{v}\right.$ ) oxgall bile (Sigma-Aldrich, Missouri, US). The mixtures were incubated at $37^{\circ} \mathrm{C}$. Samples were taken at various times ( $0 \mathrm{~h}$ and $3 \mathrm{~h}$ ), serially 10-fold-diluted using phosphate-buffered saline, PBS ( $\mathrm{pH}$ 7.4), and plated in duplicate onto nutrient agar (Oxoid, Basingstoke, UK). The plates were incubated at $37^{\circ} \mathrm{C}$ for $24 \mathrm{~h}$. After the incubation period, viable bacterial colonies were counted and recorded.

For acid tolerance, the isolates were incubated overnight in nutrient broth at $37^{\circ} \mathrm{C}$. Overnight cultures were harvested by centrifugation $\left(1500 \times \mathrm{g}, 4^{\circ} \mathrm{C}, 20 \mathrm{~min}\right)$. Harvested cells were washed twice with phosphate-buffered saline (PBS) before being resuspended into nutrient broth ( $\mathrm{pH} 7.0)$ which acts as control and nutrient broth ( $\mathrm{pH} 2.0$ ), adjusted with $0.1 \mathrm{M} \mathrm{HCl}$. Samples were withdrawn after a time interval of $0 \mathrm{~h}$ and $3 \mathrm{~h}$ and were serially diluted in phosphate-buffered saline (PBS, pH 7.4) before being plated onto nutrient agar plates and incubated at $37^{\circ} \mathrm{C}$ for $24 \mathrm{~h}$. Cell viability was assessed by the plate count method, and the results are expressed as $\log \mathrm{CFU} / \mathrm{mL}$. Both experiments were performed in triplicate.

The survival rate (SR) was calculated according to the equation below:

$$
\mathrm{SR}=(N 1 / N 0 \times 100 \%)
$$

where $N 1(\log C F U / m L)$ is the total viable count of selected species after treatment $(3 \mathrm{~h})$, and N0 $(\log \mathrm{CFU} / \mathrm{mL})$ represents the total viable count of selected species before treatment $(0 \mathrm{~h})$. A CFU is a colony-forming unit.

\subsubsection{Hydrophobicity}

Bacterial adhesion was determined to assess the adherence potential of microorganisms to surface hydrocarbons, which is a measure of adhesion to epithelial cells of the gut. The hydrophobicity of the selected Bacillus isolates was measured according to the method of Kos et al. [30], with some modifications. Following overnight incubation, bacteria were harvested in the stationary phase by centrifugation at $1500 \times \mathrm{g}$ for $15 \mathrm{~min}$, washed once, and resuspended in phosphate-buffered saline (PBS), $\mathrm{pH} 7.4$, to an absorbance $(A=600 \mathrm{~nm})$ of about $0.25 \pm 0.05\left(A_{0}\right)$ in order to standardize the number of bacteria $\left(10^{7}-10^{8} \mathrm{CFU} / \mathrm{mL}\right)$. Then, an equal volume of xylene (Fisher Scientific, Waltham, MA, USA) was added. After a 10 -min preincubation at $37^{\circ} \mathrm{C}$, the cell suspensions were mixed well through vortexing for $2 \mathrm{~min}$ and were incubated at $37^{\circ} \mathrm{C}$ for $1 \mathrm{~h}$ for aqueous and organic phase separation. The aqueous phase was carefully removed after incubation, and its absorbance was measured at $600 \mathrm{~nm}$ $\left(A_{1}\right)$. The percentage of bacterial adhesion to solvent was calculated as:

$$
\begin{gathered}
\text { Auto-aggregation }(\%)=1-\left(\mathrm{A}_{1} / \mathrm{A}_{0}\right) \times 100, \\
\mathrm{~A}_{0}=\text { Absorbance at } 0 \mathrm{~h}(600 \mathrm{~nm}), \\
\mathrm{A}_{1}=\text { Absorbance at } 1 \mathrm{~h}(600 \mathrm{~nm}) .
\end{gathered}
$$

\subsubsection{Autoaggregation}

Autoaggregation assays were performed according to Del Re et al. [31] with certain modifications. Bacteria were grown overnight at $37^{\circ} \mathrm{C}$ in nutrient broth (Oxoid, Basingstoke, UK). The cells were harvested by centrifugation at $5000 \times g$ for $15 \mathrm{~min}$ and washed twice in phosphate-buffered saline (PBS). The initial concentration was adjusted to an optical density (OD) $(A=600 \mathrm{~nm})$ of $0.25 \pm 0.05\left(A_{0}\right)$ to give viable counts of approximately $10^{8} \mathrm{CFU} / \mathrm{mL}$. Cell suspensions $(4 \mathrm{~mL})$ were mixed by vortexing for $10 \mathrm{~s}$, and autoaggregation was determined over $24 \mathrm{~h}$ of incubation at $37^{\circ} \mathrm{C}$. In addition, $1 \mathrm{~mL}$ of the upper suspension was transferred to another tube, and the absorbance $(A)$ was measured at $600 \mathrm{~nm}$. The autoaggregation percentage is expressed as

$$
\text { Auto-aggregation }(\%)=1-\left(\mathrm{A}_{\mathrm{t}} / \mathrm{A}_{0}\right) \times 100 \text {, }
$$


$A_{0}=$ Absorbance at $0 \mathrm{~h}(600 \mathrm{~nm})$,
$A_{t}=$ Absorbance at $24 \mathrm{~h}(600 \mathrm{~nm})$.

\subsection{Safety Assessment}

\subsubsection{Antibiotic Susceptibility}

The antibiotic susceptibility of the selected Bacillus strains was tested using a disk diffusion method according to Clinical and Laboratory Standard Institute (CLSI) performance standards for antimicrobial susceptibility testing [22]. Eleven kinds of antibiotics (Oxoid, Basingstoke, UK) were used: Ampicillin (AMP, $10 \mu \mathrm{g})$, Chloramphenicol (C, $30 \mu \mathrm{g})$, Ciprofloxacin (CIP, $5 \mu \mathrm{g})$, Erythromycin $(\mathrm{E}, 15 \mu \mathrm{g})$, Gentamycin $(\mathrm{CN}, 10 \mu \mathrm{g})$, Kanamycin $(\mathrm{K}, 30 \mu \mathrm{g})$, Tetracycline (TE, $30 \mu \mathrm{g})$, Teicoplanin (TEC, $30 \mu \mathrm{g}$ ), Vancomycin (VA, $30 \mu \mathrm{g}$ ), Rifampicin (RD, $30 \mu \mathrm{g})$, and Streptomycin (S, $10 \mu \mathrm{g})$. Bacillus cultures, adjusted to approximately $1 \times 10^{8} \mathrm{CFU} / \mathrm{mL}$ using the $0.5 \mathrm{McFarland}$ standard, were spread onto nutrient agar plates. Antibiotic discs were loaded onto the agar. The diameter of the inhibition zone for each antibiotic was detected after incubation at $37^{\circ} \mathrm{C}$ for $24 \mathrm{~h}$.

\subsubsection{Blood Hemolysis}

The selected Bacillus strains were streaked on Columbia sheep blood agar containing 5\% (w/v) sheep's blood (Oxoid, Basingstoke, UK) and incubated at $37^{\circ} \mathrm{C}$ for $24 \mathrm{~h}$ [32].

\section{Results}

\subsection{Isolation and Preliminary Detection of Bacillus Isolates}

Aerobic bacteria were isolated from all samples of stingless bee honey with varied concentrations: the mean values were between $9.7 \times 10^{0} \mathrm{CFU} / \mathrm{g}$ and $3.67 \times 10^{2} \mathrm{CFU} / \mathrm{g}$. Out of 5 honey samples, a total of 58 isolates of different morphological characteristics were selected and identified as Bacillus species based on early morphological examination. The selected colonies appeared to be circular and creamy and were not pigmented.

The shapes of the colonies were examined on the plates after incubation periods of $24 \mathrm{~h}$ at $37^{\circ} \mathrm{C}$. The isolates were initially identified using morphological and biochemical tests. Microscopic characterization proved that $94 \%$ of them were Gram-positive and rod-shaped or also known as Bacillus (Table 1). The Gram-positive and catalase positive isolates were further tested for their tolerance of $7 \%$ $\mathrm{NaCl}$, as this is one of the desirable technological properties of probiotic bacteria. Out of 58 isolates, only 23 of them were able to tolerate high concentrations of $7 \% \mathrm{NaCl}$ (Table 1) and were therefore selected for further identification using $16 \mathrm{~S}$ rRNA gene sequence analysis.

Table 1. Preliminary selection of Bacillus strains isolated from stingless bee honey from different geographical locations. CFU: colony-forming unit.

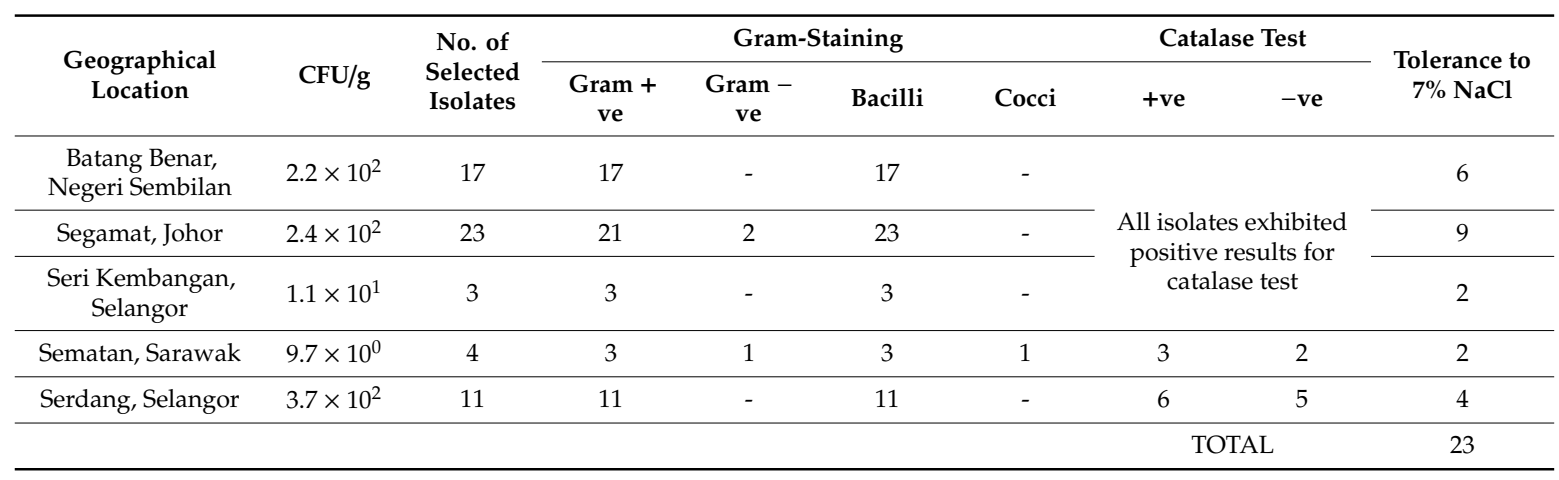




\subsection{Molecular Identification through $16 S$ rRNA Gene Sequence Analysis}

In general, a 16S rRNA gene sequence analysis of 23 selected isolates revealed that the dominant Bacillus species in this study were B. pumilus (34\%) and B. altitudinis (33\%), followed by B. megaterium $(13 \%)$, B. amyloliquefaciens ( $8 \%$ ), B. aryabhattai ( $8 \%$ ), and B. subtilis ( $4 \%$ ) (with $98 \%-100 \%$ similarities). Sequences of the 16S rRNA genes from the 23 new isolates of Bacillus were deposited in the GenBank, National Center of Biotechnology Information (NCBI) database. To further examine the phylogenetic affiliation, the 16S rRNA gene sequences of all isolates were aligned with eight closely related reference sequences (Figure 1).

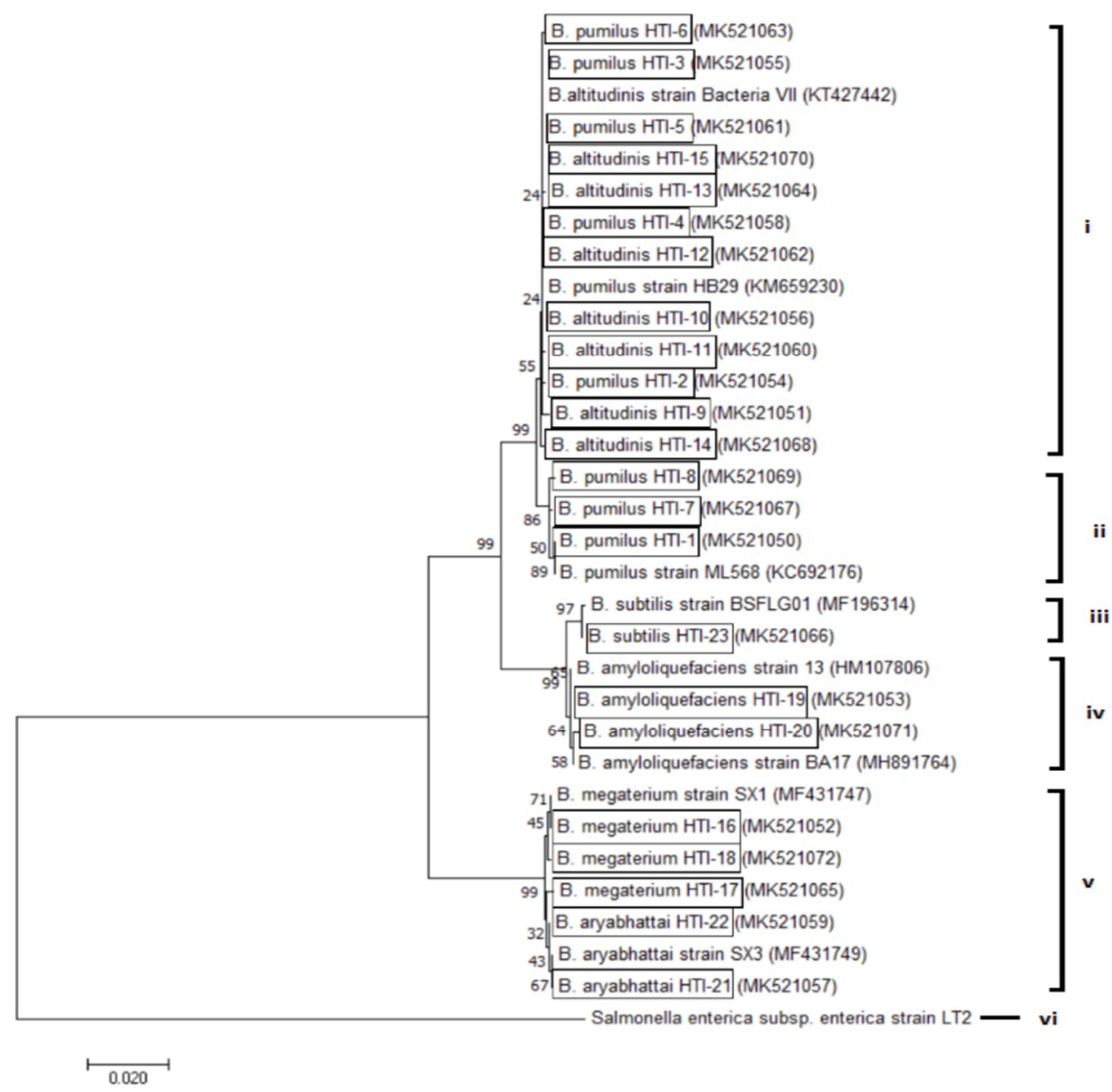

Figure 1. Evolutionary relationships of taxa. The evolutionary history was inferred using the neighbor-joining method. An optimal tree with the sum of branch lengths $=0.34080293$ is shown. The percentage of replicate trees in which the associated taxa clustered together in the bootstrap test (1000 replicates) is shown next to the branches. The tree is drawn to scale, with branch lengths in the same units as those of the evolutionary distances used to infer the phylogenetic tree. The evolutionary distances were computed using the maximum composite likelihood method and are in the units of the number of base substitutions per site. The analysis involved 32 nucleotide sequences. All positions containing gaps and missing data were eliminated. There were a total of 1405 positions in the final dataset. Evolutionary analyses were conducted in MEGA7.

\subsection{Distribution of the Bacillus Species Isolated from Stingless Bee Honey from Different Geographical} Locations

In the results, the honey samples from Batang Benar, Negeri Sembilan, and Serdang (Selangor) showed more variation in their Bacillus species compared to the other samples. Even though the species of bacteria and the number of colonies differed between the sites sampled, B. pumilus and B. altitudinis 
were the most widely distributed, as they were detected in four out of five samples of raw H. itama honey collected from different geographical locations (Figure 2). Our results coincide with a study on Argentine honeys, where the presence of B. pumilus, together with B. cereus and B. laterosporus, was found among the 70 samples examined [33]. Recently, Bacillus spp. were also reported as the most frequently isolated bacteria in honey, making up $67 \%$ of total isolates [34].

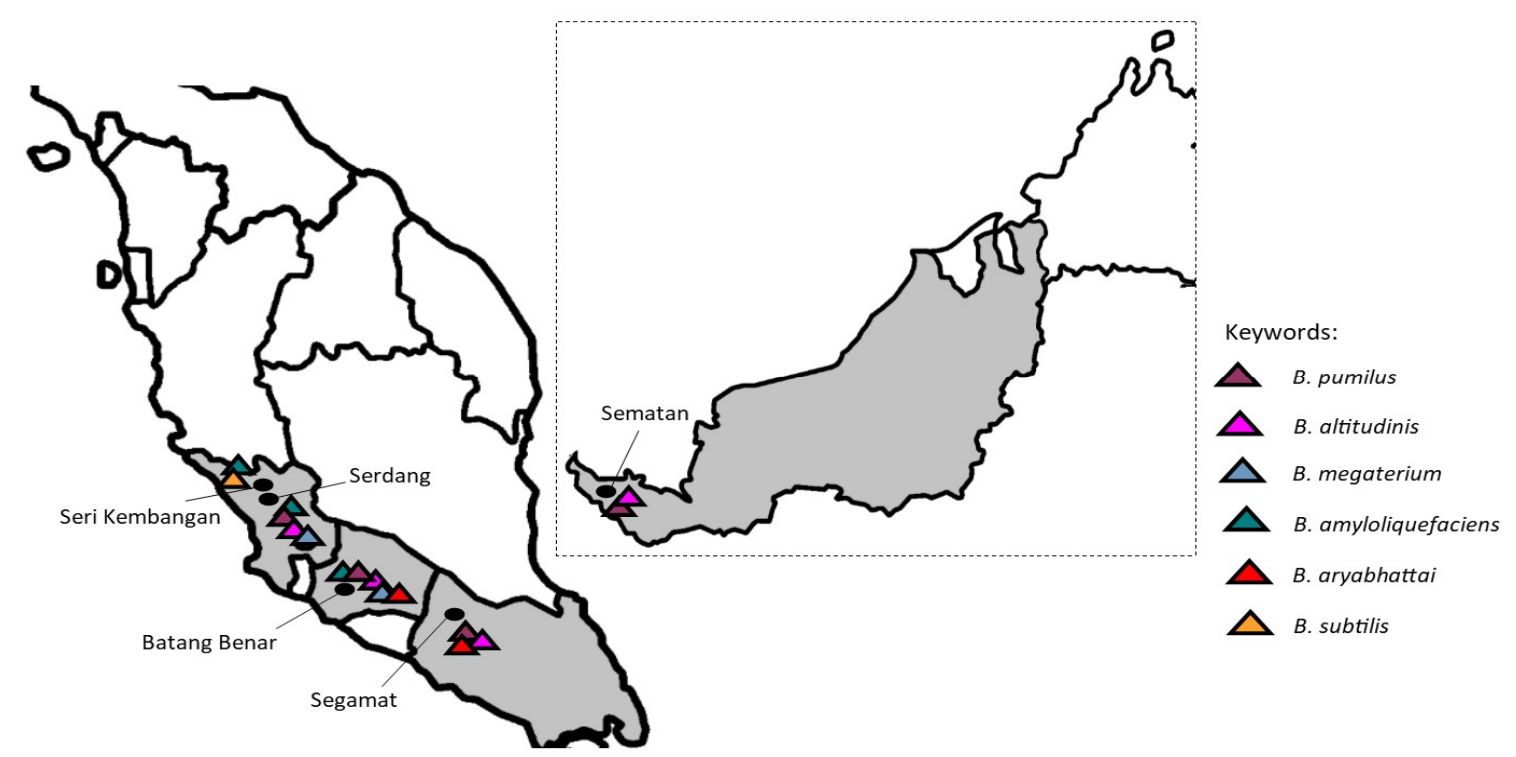

Figure 2. Distribution of the Bacillus species isolated from stingless bee (Heterotrigona itama) honey from different geographical locations.

\subsection{Antimicrobial Test against Pathogenic Bacteria}

The antagonistic activity of the isolates in this study was evaluated against Gram-positive and Gram-negative pathogenic bacteria: S. aureus, B. cereus, S. thyphimurium, E. coli, K. pneumonia, and P. aeruginosa. The results were compared to a commercial probiotic strain, Lactobacillus rhamnosus GG (Table 2). Nineteen isolates that were Gram-positive bacteria, rod-shaped, catalase-positive, and were able to grow in the presence of $7 \% \mathrm{NaCl}$ were selected. These strains exhibited inhibitory effects against at least one of the tested pathogens, except for B. pumilus HTI-3, B. megaterium HTI-16, B. megaterium HTI-17, B. megaterium HTI-18, B. aryabhattai HTI-21, and B. aryabhattai HTI-22. Two isolates with the most excellent antagonistic activity against the tested bacteria were B. amyloliquefaciens HTI-19 and B. subtilis HTI-23, where the degree of inhibition spectrum of B. amyloliquefaciens HTI-19 were almost comparable to L. rhamnosus GG (Figure 3)). B. amyloliquefaciens HTI-19 was able to inhibit the growth of all pathogenic bacteria in this study except for K. pneumoniae, while B. subtilis HTI-23 could inhibit four out of six pathogenic bacteria. The remaining strains exhibited remarkable but lower antagonistic effects in comparison to B. amyloliquefaciens HTI-19 and B. subtilis HTI-23. 
Table 2. Antagonistic activities of Bacillus species against six different pathogenic bacteria.

\begin{tabular}{|c|c|c|c|c|c|c|}
\hline \multirow[b]{2}{*}{ Bacterial Isolates } & \multicolumn{6}{|c|}{ Inhibition Zones against Pathogenic Bacteria, mm } \\
\hline & $\begin{array}{l}\text { Staphlococcus } \\
\text { aureus }\end{array}$ & $\begin{array}{l}\text { Bacillus } \\
\text { cereus }\end{array}$ & $\begin{array}{l}\text { Salmonella } \\
\text { thyphimurium }\end{array}$ & $\begin{array}{l}\text { Escheria } \\
\text { coli }\end{array}$ & $\begin{array}{c}\text { Klebsiella } \\
\text { pneumonia }\end{array}$ & $\begin{array}{l}\text { Pseudomonas } \\
\text { aeruginosa }\end{array}$ \\
\hline B. pumilus HTI-1 & +++ & NI & NI & NI & NI & NI \\
\hline B. pumilus HTI-2 & +++ & NI & NI & NI & NI & NI \\
\hline B. pumilus HTI-3 & $\mathrm{NI}$ & NI & NI & NI & NI & NI \\
\hline B. pumilus HTI-4 & ++ & NI & NI & NI & + & NI \\
\hline B. pumilus HTI-5 & ++ & NI & NI & NI & NI & NI \\
\hline B. pumilus HTI-6 & +++ & NI & NI & NI & NI & NI \\
\hline B. pumilus HTI-7 & +++ & ++ & NI & NI & ++ & NI \\
\hline B. pumilus HTI-8 & +++ & NI & NI & NI & NI & NI \\
\hline B. altitudinis HTI-11 & NI & NI & NI & NI & NI & ++ \\
\hline B. altitudinis HTI-14 & +++ & NI & NI & NI & NI & NI \\
\hline B. altitudinis HTI-15 & +++ & NI & NI & NI & NI & NI \\
\hline B. megaterium HTI-16 & NI & NI & NI & NI & NI & NI \\
\hline B. megaterium HTI-17 & NI & NI & NI & NI & NI & NI \\
\hline B. megaterium HTI-18 & NI & NI & NI & NI & NI & $\mathrm{NI}$ \\
\hline B. amyloliquefaciens HTI-19 & +++ & ++ & ++ & ++ & NI & + \\
\hline B. amyloliquefaciens HTI-20 & +++ & NI & NI & +++ & NI & NI \\
\hline B. aryabhattai HTI-21 & NI & NI & NI & NI & NI & NI \\
\hline B. aryabhattai HTI-22 & NI & NI & NI & NI & NI & NI \\
\hline B. subtilis HTI-23 & + & NI & +++ & NI & ++ & ++ \\
\hline L. rhamnosus GG & +++ & +++ & +++ & +++ & ++ & +++ \\
\hline Tetracycline(20ug/ $\mu \mathrm{l})$ & +++ & +++ & +++ & +++ & +++ & +++ \\
\hline
\end{tabular}

Note: clear zone around well; +: 1-3 mm; ++: 3-5 mm; +++: >5 mm; NI: no inhibition zone was detected.

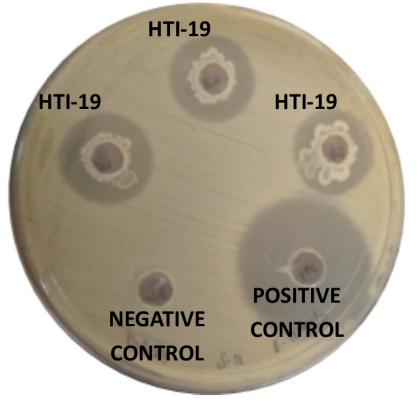

(a)

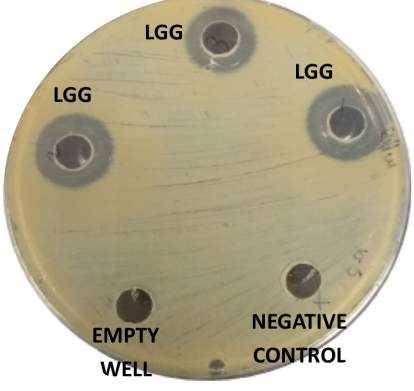

(b)

Figure 3. Inhibition zone of (a) potential probiotic B. amyloliquefaciens HTI-19 (HTI-19) against Staphylococcus aureus and (b) commercial probiotic Lactobacillus rhamnosus GG (LGG) against S. aureus.

\subsection{Tolerance to Acidic Conditions and Bile Salts}

The effect of simulated gastrointestinal conditions on the viability of B. amyloliquefaciens HTI-19 and B. subtilis HTI-23 in comparison to L. rhamnosus GG is presented in Table 3. After exposure to acidic conditions ( $\mathrm{pH} 2.0$ ) and $0.3 \%$ bile salt solution for $3 \mathrm{~h}$, the survival rates of B. amyloliquefaciens HTI-19 and B. subtilis HTI- 23 were found to be $>85 \%$. In addition, both isolates exhibited significantly high survival rates in $0.3 \%$ bile salt solution compared to L. rhamnosus GG.

Table 3. The survival of selected probiotic Bacillus isolates in simulated gastrointestinal conditions.

\begin{tabular}{|c|c|c|}
\hline \multirow{3}{*}{ Isolates } & \multicolumn{2}{|c|}{ Survival Rates, $\%$} \\
\hline & Acid Tolerance & Bile Tolerance \\
\hline & pH 2.0 & $0.3 \%$ \\
\hline B. amyloliquefaciens HTI-19 & $86.56^{a}$ & $129.10^{\mathrm{a}}$ \\
\hline B. subtilis HTI-23 & $86.72^{\mathrm{a}}$ & $140.50^{\mathrm{b}}$ \\
\hline L. rhamnosus GG & $97.46^{\mathrm{b}}$ & $106.76^{c}$ \\
\hline
\end{tabular}

a_c: Different superscript letters in the same column indicate statistical differences in each strain at the level of $p<0.05$ as measured by Tukey's test. All the results were obtained after $3 \mathrm{~h}$, and the values are represented as mean SDs of three independent replicates. 


\subsection{Cell Adhesion Activity of Bacillus Species}

Autoaggregation is a probiotic characteristic that pertains to the entrapment of bacteria in an aggregated form, which allows for the stability of microbial strains in the gastrointestinal tract (GIT), resulting from lesser exposure to inhospitable intestinal conditions [35]. After $24 \mathrm{~h}$ of incubation, B. amyloliquefaciens HTI-19 and B. subtilis HTI-23 showed autoaggregation abilities of $84.13 \%$ and $57.51 \%$, respectively (Table 4). Interestingly, the autoaggregation and hydrophobicity percentage of both Bacillus species showed no significant difference from L. rhamnosus GG.

Table 4. Cell adhesion activity of selected probiotic species.

\begin{tabular}{ccc}
\hline Isolates & Autoaggregation (\%) & Hydrophobicity (\%) \\
\hline B. amyloliquefaciens HTI-19 & $84.13^{\mathrm{a}}$ & $53.64^{\mathrm{a}}$ \\
B. subtilis HTI-23 & $57.51^{\mathrm{b}}$ & $60.82^{\mathrm{a}}$ \\
L. rhamnosus GG & $69.99^{\mathrm{ab}}$ & $61.04^{\mathrm{a}}$ \\
\hline
\end{tabular}

a,b: Different superscript letters in the same column indicate statistical differences in each strain at the level of $p<0.05$ as measured by Tukey's test. All the values are represented as mean SDs of three independent replicates.

\subsection{Antibiotic Susceptibility and Hemolytic Activity}

The antibiotic susceptibility of the three probiotic Bacillus strains was tested using two groups of antibiotics categorized by their mechanisms. The two groups were cell wall inhibitors, including ampicillin, ciprofloxacin, kanamycin, streptomycin, and vancomycin. Protein synthesis inhibitors included are chloramphenicol, erythromycin, gentamicin, tetracycline, and teicoplanin. Antibiotics that could perform both mechanisms of action depending on the concentration and susceptibility of the bacteria like rifampicin were also included [36]. B. amyloliquefaciens HTI-19 and B. subtilis HTI-23 were susceptible to all antibiotics with different mechanisms of action, while L. rhamnosus GG was observed to be resistant to teicoplanin and vancomycin. Meanwhile, B. amyloliquefaciens HTI-19 showed $\alpha$-hemolytic activity, while B. subtilis HTI-23 exhibited $\gamma$-hemolytic activity on a blood agar plate (Table 5).

Table 5. Antibiotic susceptibility of Bacillus isolates to antibiotics. Antibiotics: AMP10 (ampicillin, $10 \mu \mathrm{g})$; C30 (chloramphenicol, $30 \mu \mathrm{g}$ ); CIP5 (ciprofloxacin, $15 \mu \mathrm{g}$ ); E15 (erythromycin, $15 \mu \mathrm{g}$ ); CN10 (gentamicin, $10 \mu \mathrm{g}$ ); K30 (kanamycin, $30 \mu \mathrm{g}$ ); TE30 (tetracycline, $30 \mu \mathrm{g}$ ); TEC30 (teicoplanin, $30 \mu \mathrm{g}$ ); VA30 (vancomycin, $30 \mu \mathrm{g}$ ); RD30 (rifampicin, $30 \mu \mathrm{g}$ ); and S10 (streptomycin, $10 \mu \mathrm{g}$ ). R: resistant; S: susceptible.

\begin{tabular}{|c|c|c|c|c|c|c|c|c|c|c|c|c|}
\hline \multirow{2}{*}{ Isolates } & \multicolumn{11}{|c|}{ Susceptibility to Antibiotics } & \multirow{2}{*}{$\begin{array}{c}\text { Hemolytic } \\
\text { Activity }\end{array}$} \\
\hline & AMP10 & $\mathrm{C} 30$ & CIP5 & E15 & CN10 & K30 & TE30 & TEC30 & VA30 & RD30 & S10 & \\
\hline $\begin{array}{c}\text { B. } \\
\text { amyloliquefaciens } \\
\text { HTI-19 }\end{array}$ & $S$ & $S$ & S & S & S & $S$ & $S$ & $S$ & S & $S$ & S & $\alpha$-hemolytic \\
\hline B. subtilis HTI-23 & $S$ & $S$ & S & $S$ & $S$ & S & S & S & S & S & S & $\gamma$-hemolytic \\
\hline L. rhamnosus GG & S & S & S & S & S & S & S & $\mathrm{R}$ & $\mathrm{R}$ & S & S & $\gamma$-hemolytic \\
\hline
\end{tabular}

\section{Discussion}

The amount of aerobic bacteria detected in the fresh honey of stingless bees could be considered relatively low, with a mean value of $1.7 \times 10^{2} \mathrm{CFU} / \mathrm{g}$, compared to its other byproducts, such as beebread and propolis $\left(1.83 \times 10^{6} \mathrm{CFU} / \mathrm{g}\right)[12,37]$. This is supported by the results from a previous study, as the presence of aerobic bacteria in honey was also detected in the range of $5.7 \times 10^{0}$ to $52.8 \times 10^{4} \mathrm{CFU} / \mathrm{g}$ [38]. The reason for this is that most bacteria are not able to multiply in honey due to the physicochemical properties of honey itself, such as high osmolarity, high sugar concentration, low $\mathrm{pH}$, and the presence of many agents, including hydrogen peroxide and phytochemicals $[13,39]$. These conditions provide a stressful environment for bacteria, thus preventing the growth or even survival of different types of 
bacteria in honey. Therefore, a high number of aerobic bacteria could indicate contamination during processing, handling, or storing.

In a previous study by Esawy et al. [8], the strains isolated from honeybees were rod-shaped, Gram-positive, motile, and spore-forming. All of the isolates were moderately thermophilic and were preliminary identified as Bacillus spp. The results are in agreement with the results obtained in our study, where most of the bacterial isolates were also Gram-positive and rod-shaped. Potential probiotic species, B. amyloliquefaciens and B. subtilis, were also isolated in this study. Previously, both Bacillus species had been isolated from the gut and honey of Apis mellifera [40]. Probiotic bacteria were commonly selected from the Gram-positive bacteria, as the cell surface structures of Gram-positive microbes can ensure effective bacterial adhesion to the intestinal cell wall [41]. This characteristic is really important to ensure the successful colonization of the host.

A detailed analysis of the 16S rRNA gene sequences of the isolates exhibited significant diversity even in the case where bacteria were isolated from the same species of stingless bee. Environmental factors such as nectar, water, and pollen might be responsible for the diversity of the strains. A recent study found that the highest microbial diversity was found in multifloral honey [13]. Recently, the presence of B. altitudinis in stingless bee honey, H. itama, was reported for the first time [12]. B. altitudinis had been previously found in Apis mellifera honey together with other Bacillus isolates, namely $B$. licheniformis, B. safensis, B. zhangzhouensis, and B. xiamenensis [13]. This showed that B. altitudinis and B. pumilus have a niche in both honey samples of $H$. itama and A. mellifera. Interestingly, this species has been identified as one of the starter culture strains in rice wine [42]. Thus, the presence of these species in honey might suggest the roles of $B$. altitudinis in the fermentation of both A. mellifera and $H$. itama honeys.

B. amyloliquefaciens HTI-19 and B. subtilis HTI-23, which are associated with fermentation products, were successfully isolated from stingless bee honey. These species, together with $B$. methylotrophicus, B. safensis, and B. vallismortis, have been previously detected in A. mellifera honey, Korean traditional soy sauce, and the fermented seed condiment Kantong [8,43,44]. In fact, an assessment of cultivable microorganisms in honey has reported B. amyloliquefaciens to be the most prevalent strain among 13 species isolated from 38 honeys [45]. The 16S rRNA gene sequence of the B. subtilis HTI-23 isolate exhibited 99\% sequence similarity to the B. subtilis strain BSFLG01 isolated from the black soldier fly larval gut, which is known as an invading species that has caused the mass infestation of domesticated stingless bees in Malaysia [46]. Hence, it was assumed that B. subtilis is a natural inhabitant in the honey.

Although it appears that there was no correlation between the microbial diversity and the geographical origin, the distinction of Bacillus strains found in the H. itama honey may be explained by the uses of the tubular proboscis of the bees while collecting nectar from various floral sources [47]. During the feeding process, the external surfaces of the bee's frontal organs are in close proximity to the nectar, and bacteria are then inoculated into the honey, which confirms the role of bees as bacterial vectors. Strains of B. amyloliquefaciens ssp. plantarum and B. methylotrophicus that have plant growth-promoting abilities are frequently isolated from plant material and/or soil [48]. However, bees might contribute to the presence of these bacteria strains in stingless bee honey during the pollination of different plants. Hence, it was hypothesized that Bacillus strains isolated from H. itama honey might come from floral sources, transferred by the H. itama bee during its foraging flight [49].

Another purpose of this study was to select the bacteria that exhibited excellent antimicrobial activity against pathogenic bacteria. The successful selection of antimicrobial producers from honey has been reported by several different authors [13]. For example, Manhar et al. [50] reported that B. amyloliquefaciens AMS1 inhibited the growth of L. monocytogenes and K. pneumoniae, but did not affect the growth of B. cereus, Yersinia enterocolitica, and Salmonella entericatyphimurium. In contrast with our study, the B. amyloliquefaciens strain HTI-19 exhibited a wider antimicrobial spectrum against pathogens, as it can inhibit the growth of $S$. thyphimurium and B. cereus. Many attempts were have been made to prevent the growth of $B$. cereus in food products, because $B$. cereus is known to be one of the major threats to food safety. Further characterization of B. amyloliquefaciens HTI-19 will be particularly 
helpful in food industries. It has been reported that $B$. amyloliquefaciens strains were able to inhibit the growth of a variety of fungal pathogens because of their ability to produce a vast array of antibiotics, such as bacillomycin, zwittermicin, bacilysin, difficidin, and fengycin [51,52].

In addition, the growth of $S$. aureus was successfully inhibited by most of the Bacillus strains in this study. Since this study used cell-free supernatant for the antimicrobial activity assay, the potential antimicrobial metabolites produced were bacteriocin, hydrogen peroxide, and lactic and propionic acid [53]. Despite a few Bacillus spp. being known as toxin producers, some of the Bacillus strains are already considered to be safe probiotic bacteria. These include B. endophyticus, B. subtilis, $B$. amyloliquefaciens, B. pumilus, and B. licheniformis $[8,43,50]$. Bacillus subtilis has also been shown to have a broad spectrum of antimicrobial activities over diverse pathogenic fungal and bacteria [54].

Tolerance to low-acidic gastric and bile-rich intestinal environments is one of the essential properties required for probiotic cultures in order to function effectively in the intestines, because such conditions provide a stressful environment for bacteria [55]. The results obtained after $3 \mathrm{~h}$ established the possibility that the strain can survive under acidic conditions that exist in the human gut ( $\mathrm{pH} 2-5)$, as the transit time of the food along the human gut is a maximum of $3 \mathrm{~h}$ [10]. This result suggests that B. amyloliquefaciens species have high levels of survival in simulated gastric juices (pH 2.0), as previously reported by Wang et al. [56]. Bile salts have been reported to inhibit bacterial growth by disrupting cell membranes. Some studies have observed that some Bacillus spp. are weakly tolerant or sensitive to bile salt concentrations [56]; however, the present results showed that the survival rates of B. amyloliquefaciens HTI-19 and B. subtilis HTI- 23 in $0.3 \%$ bile salt solution were significantly higher $(p<0.05)$ than for L. rhamnosus GG. Tolerance to bile salt enables a probiotic strain to survive, grow, and exert itself during gastrointestinal transit [36].

The adherence ability of probiotic bacteria to intestinal epithelial cells involves various types of interactions, including hydrophobicity and autoaggregation [57]. The ability to adhere to epithelial cells and mucosal surfaces is considered to be a prerequisite for ideal probiotics. In this study, xylene was chosen as an apolar solvent because it reflects cell surface hydrophobicity and hydrophilicity [58]. As the results showed, both strains exhibited high hydrophobicity with xylene, indicating good bacterial adhesion to hydrocarbons. Patel et al. [25] have reported that the autoaggregation activity of $B$. subtilis DET6 is about $60 \%$, which is in agreement with our study. These properties are crucial for probiotic cultures in colonizing epithelium cells in the digestive tract to prevent elimination by peristalses and to become functionally effective in intestinal balance [10]. Autoaggregation is also strongly correlated with cell adhesion to the digestive tract, which is responsible for the probiotic characteristics of bacteria [30]. The results showed that the two probiotic strains had high cell hydrophobicity and autoaggregation, indicating good cell adhesion ability.

The antibiotic susceptibility of probiotics should be measured for safety purposes. Antibiotic resistance gene transmission can occur due to transposons, plasmids, and bacterial gene mutations, leading to new antibiotic-resistant strains [59]. An antibiotic susceptibility test indicated that B. amyloliquefaciens HTI-19 and B. subtilis HTI-23 were sensitive to all antibiotics included in this study. Resistance to a given antibiotic can be inherent to a bacterial species or genus. In addition, $\gamma$-hemolysis and $\alpha$-hemolysis are considered to be safe, and $\beta$-hemolysis is considered to be harmful [60] as $\beta$-hemolysis is an indication that bacteria contain cytotoxic phospholipases [61].

\section{Conclusions}

The results of the present research demonstrated that honey of different geographical origins in Malaysia can be considered as a reservoir of bacteria with antimicrobial activities, with potential for use as probiotic cultures. Interestingly, B. amyloliquefaciens HTI-19 not only showed a broad range of antimicrobial activities that could inhibit both Gram-positive and Gram-negative bacteria, but also was able to inhibit the growth of B. cereus and S. thyphimurium, which had not been inhibited previously by a different strain of B. amyloliquefaciens species in other studies. Two Bacillus strains (B. amyloliquefaciens HTI-19 and B. subtilis HTI-23) that were isolated from stingless bee honey possess great potential as 
probiotics for human and animal use and as fermentation starter cultures. This was supported by positive probiotic characteristics such as high survivability in the artificial modified digestive tract system, wide antimicrobial spectra, and safety confidence with regard to antibiotic susceptibility and nonhemolytic activity. The current findings suggest that these strains may exhibit the ability to remain viable after exposure to stressful environments in the gastrointestinal tract of humans and animals, thus being able to be functionally effective in the intestine. As probiotic effects on certain noncommunicable diseases have proven to be strain-specific, further investigation into these isolates may lead to the discovery of new beneficial probiotic strains that can be used in the therapeutic field.

Author Contributions: F.A.Z.A. worked on the sample collection, the research methodology, data analysis, and the preparation of the first draft of the manuscript. S.S. and N.Z. contributed to the design of the research methodology, results and data interpretation, discussion, and revision of the manuscript. M.I., K.W.C., and N.I. were involved in the research idea consultation and the discussion of the final results and conclusions. N.M.E. was head of the project and reviewed the manuscript. M.A.M.L. secured funding for the project and was involved in consultation of the research idea. All authors have read and agreed to the published version of the manuscript.

Funding: This research was funded by the Transdisciplinary Research Grant Scheme (TRGS) by the Ministry of Education (MOE), Malaysia, reference code TRGS/1/2016/UPM/01/5/4.

Acknowledgments: F.A.Z.A. is supported by a Graduate Research Fellowship (GRF) scholarship from Universiti Putra Malaysia.

Conflicts of Interest: The authors declare no conflict of interest. The funders had no role in the design of the study; in the collection, analyses, or interpretation of data; in the writing of the manuscript; or in the decision to publish the results.

\section{References}

1. Lee, S.; Duwal, R.K.; Lee, W. Diversity of stingless bees (Hymenoptera, Apidae, Meliponini) from Cambodia and Laos. J. Asia-Pac. Entomol. 2016, 19, 947-961. [CrossRef]

2. Codex. Codex Alimentarius Commission Standards; CODEX Stand. HONEY: Rome, Italy, 2001.

3. Amin, F.A.Z.; Sabri, S.; Mohammad, S.M.; Ismail, M.; Chan, K.W.; Ismail, N.; Norhaizan, M.E.; Zawawi, N. Therapeutic Properties of Stingless Bee Honey in Comparison with European Bee Honey. Adv. Pharmacol. Sci. 2018, 2018, 6179596.

4. $\quad$ Lage, L.G.; Coelho, L.L.; Resende, H.C.; Tavares, M.G.; Campos, L.A.; Fernandes-Salomão, T.M. Honey physicochemical properties of three species of the Brazilian Melipona. Anais Academia Brasileira Ciências 2012, 84, 605-608. [CrossRef]

5. Da Silva, P.M.; Gauche, C.; Gonzaga, L.V.; Costa, A.C.O.; Fett, R. Honey: Chemical composition, stability and authenticity. Food Chem. 2016, 196, 309-323. [CrossRef] [PubMed]

6. Cheng, M.Z.S.Z.; Ismail, M.; Chan, K.W.; Ooi, D.J.; Ismail, N.; Zawawi, N.; Mohd Esa, N. Comparison of Sugar Content, Mineral Elements and Antioxidant Properties of Heterotrigona Itama Honey from Suburban and Forest in Malaysia. Malays. J. Med. Health Sci. 2019, 15, 104-112.

7. Nascimento, A.; Marchini, L.; Carvalho, C.; Araújo, D.; Olinda, R.; Silveira, T. Physical-Chemical Parameters of Honey of Stingless Bee (Hymenoptera: Apidae). Am. Chem. Sci. J. 2015, 7, 139-149. [CrossRef]

8. Esawy, M.A.; Awad, G.E.A.; Ahmed, E.F.; Danial, E.N.; Mansour, N.M. Evaluation of Honey as a New Reservoir for Probiotic Bacteria. Adv. Food Sci. 2012, 34, 72-81.

9. Hasali, N.H.M.; Zamri, A.I.; Lani, M.N.; Mubarak, A.; Suhaili, Z. Identification of Lactic Acid Bacteria from Meliponine Honey and Their Antimicrobial Activity against Pathogenic Bacteria. Am. J. Sustain. Agric. 2015, 9, 1-6.

10. Begum, S.B.; Roobia, R.R.; Karthikeyan, M.; Murugappan, R. Validation of nutraceutical properties of honey and probiotic potential of its innate microflora. LWT 2015, 60, 743-750. [CrossRef]

11. Sabaté, D.C.; Carrillo, L.; Audisio, M.C. Inhibition of Paenibacillus larvae and Ascosphaera apis by Bacillus subtilis isolated from honeybee gut and honey samples. Res. Microbiol. 2009, 160, 193-199. [CrossRef]

12. Ngalimat, M.S.; Rahman, R.N.Z.R.A.; Yusof, M.T.; Syahir, A.; Sabri, S. Characterisation of bacteria isolated from the stingless bee, Heterotrigona itama, honey, bee bread and propolis. PeerJ 2019, 7, e7478. [CrossRef] [PubMed] 
13. Pajor, M.; Worobo, R.W.; Milewski, S.; Szweda, P. The Antimicrobial Potential of Bacteria Isolated from Honey Samples Produced in the Apiaries Located in Pomeranian Voivodeship in Northern Poland. Int. J. Environ. Res. Public Health 2018, 15, 2002. [CrossRef] [PubMed]

14. Cutting, S.M. Bacillus Probiotics. Food Microbiol. 2011, 28, 214-220. [CrossRef] [PubMed]

15. Agbagwa, O.; Otokunefor, T.; Frank-Peterside, N. Preliminary Detection of Bacillus species in Commercial Honey. Br. Microbiol. Res. J. 2014, 4, 1370-1380. [CrossRef]

16. Isolauri, E.; Salminen, S.; Ouwehand, A. Microbial-Gut Interactions in Health and Disease. Probiotics. Best Pract. Res. Clin. Gastroenterol. 2004, 18, 299-313. [CrossRef]

17. Working Group Report on Drafting Guidelines for the Evaluation of Probiotics in Food; FAO/WHO: Ontario, Canada; London, UK, 2002.

18. Zhou, S.; Song, D.; Zhou, X.; Mao, X.; Zhou, X.; Wang, S.; Wei, J.; Huang, Y.; Wang, W.; Xiao, S.M.; et al. Characterization of Bacillus subtilis from Gastrointestinal Tract of Hybrid Hulong Grouper (Epinephelus Fuscoguttatus $\times$ E. Lanceolatus) and Its Effects as Probiotic Additives. Fish Shellfish Immunol. 2019, 84, 1115-1124. [CrossRef]

19. Jeon, H.-L.; Yang, S.-J.; Son, S.-H.; Kim, W.-S.; Lee, N.-K.; Paik, H.-D. Evaluation of probiotic Bacillus subtilis P229 isolated from cheonggukjang and its application in soybean fermentation. LWT 2018, 97, 94-99. [CrossRef]

20. Quigley, E.M. Prebiotics and probiotics; modifying and mining the microbiota. Pharmacol. Res. 2010, 61, 213-218. [CrossRef]

21. Desai, J.D.; Banat, I.M. Microbial production of surfactants and their commercial potential. Microbiol. Mol. Biol. Rev. 1997, 61, 47-64.

22. Stein, T. Bacillus subtilis antibiotics: Structures, syntheses and specific functions. Mol. Microbiol. 2005, 56, 845-857. [CrossRef]

23. O'Hara, A.M.; Shanahan, F. Gut Microbiota: Mining for Therapeutic Potential. Clin. Gastroenterol. Hepatol. 2007, 5, 274-284. [CrossRef] [PubMed]

24. Zeng, J.; Li, Y.-Q.; Zuo, X.-L.; Zhen, Y.-B.; Yang, J.; Liu, C.-H. Clinical trial: Effect of active lactic acid bacteria on mucosal barrier function in patients with diarrhoea-predominant irritable bowel syndrome. Aliment. Pharmacol. Ther. 2008, 28, 994-1002. [CrossRef] [PubMed]

25. Patel, A.K.; Ahire, J.J.; Pawar, S.P.; Chaudhari, B.L.; Chincholkar, S.B. Comparative Accounts of Probiotic Characteristics of Bacillus spp. Isolated from Food Wastes. Food Res. Int. 2009, 42, 505-510. [CrossRef]

26. Tajabadi, N.; Mardan, M.; Manap, M.Y.A.; Shuhaimi, M.; Meimandipour, A.; Nateghi, L. Detection and identification of Lactobacillus bacteria found in the honey stomach of the giant honeybee Apis dorsata. Apidologie 2011, 42, 642-649. [CrossRef]

27. Kumar, S.; Stecher, G.; Tamura, K. MEGA7: Molecular Evolutionary Genetics Analysis Version 7.0 for Bigger Datasets. Mol. Biol. Evol. 2016, 33, 1870-1874. [CrossRef]

28. Yilmaz, M.; Soran, H.; Beyatli, Y. Antimicrobial Activities of Some Bacillus spp. Strains Isolated from the Soil. Microbiol. Res. 2006, 161, 127-131. [CrossRef]

29. Klingberg, T.D.; Axelsson, L.; Naterstad, K.; Elsser, D.; Budde, B.B. Identification of potential probiotic starter cultures for Scandinavian-type fermented sausages. Int. J. Food Microbiol. 2005, 105, 419-431. [CrossRef]

30. Kos, B.; Šušković, J.; Vuković, S.; Sǐmpraga, M.; Frece, J.; Matošić, S. Adhesion and Aggregation Ability of Probiotic Strain Lactobacillus acidophilus M92. J. Appl. Microbiol. 2003, 94, 981-987. [CrossRef]

31. Del Re, B.; Sgorbati, B.; Miglioli, M.; Palenzona, D. Adhesion, autoaggregation and hydrophobicity of 13 strains of Bifidobacterium longum. Lett. Appl. Microbiol. 2000, 31, 438-442. [CrossRef]

32. Anand, C.; Gordon, R.; Shaw, H.; Fonseca, K.; Olsen, M. Pig and Goat Blood as Substitutes for Sheep Blood in Blood-Supplemented Agar Media. J. Clin. Microbiol. 2000, 38, 591-594.

33. Iurlina, M.O.; Fritz, R. Characterization of microorganisms in Argentinean honeys from different sources. Int. J. Food Microbiol. 2005, 105, 297-304. [CrossRef] [PubMed]

34. Wen, Y.; Wang, L.; Jin, Y.; Zhang, J.; Su, L.; Zhang, X.; Zhou, J.; Li, Y. The Microbial Community Dynamics during the Vitex Honey Ripening Process in the Honeycomb. Front. Microbiol. 2017, 8, 1649. [CrossRef]

35. Sakandar, H.A.; Kubow, S.; Sadiq, F.A. Isolation and in-vitro probiotic characterization of fructophilic lactic acid bacteria from Chinese fruits and flowers. LWT 2019, 104, 70-75. [CrossRef] 
36. Argyri, A.A.; Zoumpopoulou, G.; Karatzas, K.-A.G.; Tsakalidou, E.; Nychas, G.-J.E.; Panagou, E.Z.; Tassou, C.C. Selection of potential probiotic lactic acid bacteria from fermented olives by in vitro tests. Food Microbiol. 2013, 33, 282-291. [CrossRef] [PubMed]

37. Combey, R. Microbial and Qualitative Analyses of Stingless Bee Bread Using Dry Preservation Methods. Eur. J. Zool. Res. 2017, 5, 45-50.

38. Różańska, H. Microbiological Quality of Polish Honey. Bull. Vet. Inst. Pulawy 2011, 55, 443-445.

39. Kwakman, P.H.S.; Zaat, S.A.J. Antibacterial Components of Honey. IUBMB Life 2012, 64, 48-55. [CrossRef]

40. Wang, M.; Zhao, W.-Z.; Xu, H.; Wang, Z.-W.; He, S.-Y. Bacillus in the guts of honey bees (Apis mellifera; Hymenoptera: Apidae) mediate changes in amylase values. Eur. J. Entomol. 2015, 112, 619-624. [CrossRef]

41. Sanders, M.E.; Benson, A.; Lebeer, S.; Merenstein, D.J.; Klaenhammer, T.R. Shared mechanisms among probiotic taxa: Implications for general probiotic claims. Curr. Opin. Biotechnol. 2018, 49, 207-216. [CrossRef]

42. Lv, X.-C.; Jia, R.-B.; Li, Y.; Chen, F.; Chen, Z.-C.; Liu, B.; Chen, S.-J.; Rao, P.-F.; Ni, L. Characterization of the dominant bacterial communities of traditional fermentation starters for Hong Qu glutinous rice wine by means of MALDI-TOF mass spectrometry fingerprinting, 16S rRNA gene sequencing and species-specific PCRs. Food Control 2016, 67, 292-302. [CrossRef]

43. Lee, S.; Lee, J.; Jin, Y.-I.; Jeong, J.-C.; Chang, Y.H.; Lee, Y.; Jeong, Y.; Kim, M. Probiotic characteristics of Bacillus strains isolated from Korean traditional soy sauce. LWT 2017, 79, 518-524. [CrossRef]

44. Kpikpi, E.N.; Thorsen, L.; Glover, R.; Dzogbefia, V.P.; Jespersen, L. Identification of Bacillus species occurring in Kantong, an acid fermented seed condiment produced in Ghana. Int. J. Food Microbiol. 2014, 180, 1-6. [CrossRef] [PubMed]

45. Sinacori, M.; Settanni, L.; Sannino, C.; Francesca, N.; Moschetti, G.; Cruciata, M.; Alfonzo, A. Cultivable Microorganisms Associated with Honeys of Different Geographical and Botanical Origin. Food Microbiol. 2013, 38, 284-294. [CrossRef] [PubMed]

46. Hashim, N.A.; Bahri, A.R.S.; Basari, N.; Sharudin, N.H. Mass Infestation of Black Soldier Fly Hermetia Illucens (Diptera: Stratiomyidae) on Colonies of the Indo-Malayan Stingless Bees Geniotrigona thoracica and Heterotrigona itama. J. Biodivers. Environ. Sci. 2017, 11, 9-15.

47. Aizenberg-Gershtein, Y.; Izhaki, I.; Halpern, M. Do Honeybees Shape the Bacterial Community Composition in Floral Nectar? PLoS ONE 2013, 8, e67556. [CrossRef] [PubMed]

48. Borriss, R.; Chen, X.H.; Rueckert, C.; Blom, J.; Becker, A.; Baumgarth, B.; Fan, B.; Pukall, R.; Schumann, P.; Spröer, C.; et al. Relationship of Bacillus amyloliquefaciens Clades Associated with Strains DSM 7 T and FZB42 T: A Proposal for Bacillus amyloliquefaciens subsp. amyloliquefaciens subsp. Nov. and Bacillus amyloliquefaciens subsp. Plantarum subsp. Nov. Based on Complete Gen. Int. J. Syst. Evol. Microbiol. 2011, 61, 1786-1801.

49. Syed Yaacob, S.N.; Huyop, F.; Kamarulzaman Raja Ibrahim, R.; Wahab, R.A. Identification of Lactobacillus spp. and Fructobacillus spp. Isolated from Fresh Heterotrigona Itama Honey and Their Antagonistic Activities against Clinical Pathogenic Bacteria. J. Apic Res. 2018, 57, 395-405. [CrossRef]

50. Manhar, A.K.; Saikia, D.; Bashir, Y.; Mech, R.K.; Nath, D.; Konwar, B.K.; Mandal, M. In Vitro Evaluation of Celluloytic Bacillus amyloliquefaciens AMS1 Isolated from Traditional Fermented Soybean (Churpi) as an Animal Probiotic. Res. Vet. Sci. 2015, 99, 149-156. [CrossRef]

51. Athukorala, S.N.; Rashid, K.Y.; Fernando, W.G.D. Identification of antifungal antibiotics of Bacillus species isolated from different microhabitats using polymerase chain reaction and MALDI-TOF mass spectrometry. Can. J. Microbiol. 2009, 55, 1021-1032. [CrossRef]

52. Ajilogba, C.F. Antagonistic Effects of Bacillus Species in Biocontrol of Tomato Fusarium Wilt. Stud. Ethno-Med. 2013, 7, 205-216. [CrossRef]

53. El-Mabrok, A.S.W.; Hassan, Z.; Mokhtar, A.M.; Hussain, K.M.A.; Kahar, F.K.S.B.A. Screening of Lactic Acid Bacteria as Biocontrol against (Colletotrichum Capsici) on Chilli Bangi. Res. J. Appl. Sci. 2012, 7, 446-473.

54. Grover, M.; Nain, L.; Saxena, A.K. Comparision between Bacillus subtilis RP24 and its antibiotic-defective mutants. World J. Microbiol. Biotechnol. 2009, 25, 1329-1335. [CrossRef]

55. Jena, P.K.; Trivedi, D.; Thakore, K.; Chaudhary, H.; Giri, S.S.; Seshadri, S. Isolation and Characterization of Probiotic Properties of Lactobacilli Isolated from Rat Fecal Microbiota. Microbiol. Immunol. 2013, 57, 407-416. [CrossRef] [PubMed]

56. Wang, Y.; Zhang, H.; Zhang, L.; Liu, W.; Zhang, Y.; Zhang, X.; Sun, T. In vitro assessment of probiotic properties of Bacillus isolated from naturally fermented congee from Inner Mongolia of China. World J. Microbiol. Biotechnol. 2010, 26, 1369-1377. [CrossRef] 
57. Botes, M.; Loos, B.; Van Reenen, C.A.; Dicks, L.M.T.; Reenen, C.A. Adhesion of the probiotic strains Enterococcus mundtii ST4SA and Lactobacillus plantarum 423 to Caco-2 cells under conditions simulating the intestinal tract, and in the presence of antibiotics and anti-inflammatory medicaments. Arch. Microbiol. 2008, 190, 573-584. [CrossRef]

58. Collado, M.C.; Meriluoto, J.; Salminen, S. Adhesion and Aggregation Properties of Probiotic and Pathogen Strains. Eur. Food Res. Technol. 2008, 226, 1065-1073. [CrossRef]

59. Teuber, M.; Meile, L.; Schwarz, F. Acquired antibiotic resistance in lactic acid bacteria from food. Antonie Leeuwenhoek 1999, 76, 115-137. [CrossRef]

60. Shin, H.-J.; Choi, H.-J.; Kim, D.-W.; Ahn, C.-S.; Lee, Y.-G.; Jeong, Y.-K.; Joo, W.-H. Probiotic Potential of Pediococcus pentosaceus BCNU 9070. J. Life Sci. 2012, 22, 1194-1200. [CrossRef]

61. Sorokulova, I.B.; Pinchuk, I.V.; Denayrolles, M.; Osipova, I.G.; Huang, J.M.; Cutting, S.M.; Urdaci, M.C. The Safety of Two Bacillus Probiotic Strains for Human Use. Dig. Dis. Sci. 2008, 53, 954-963. [CrossRef]

(C) 2019 by the authors. Licensee MDPI, Basel, Switzerland. This article is an open access article distributed under the terms and conditions of the Creative Commons Attribution (CC BY) license (http://creativecommons.org/licenses/by/4.0/). 